UDC: $[612.821+616.89-02-084]-057.36:: 355.4$

DOI: 10.26697/ijes.2019.2.50

\section{Medical-Psychological Support for Military-Man of National Guard of Ukraine in Conditions of Hybrid Warfare}

Associate Professor Stadnik A. V. ${ }^{1}$

${ }^{1}$ National Academy of National Guard of Ukraine, Kharkiv, Ukraine

\section{Abstract \\ Background:}

Two world wars have occurred in the first half of the 20th century. The second half of the 20th century was full of local military conflicts in different countries. At the end of the 20th and the beginning of the 21st century, hybrid warfare became a common type of hostile military action.

Ukrainians, who were called up for military service in the army of the Russian Empire and the Soviet Union, were direct participants in these world wars.

In 1991, Ukraine declared independence. At this time, Ukraine had the third largest nuclear arsenal (after Russia and the United States). Under international security guarantees, Ukraine voluntarily abandoned its nuclear arsenal.

However, international security guarantees have been untenable against hybrid warfare. In 2014, Russia started hybrid warfare against Ukraine. Russia annexed a part of the territory of Ukraine (Crimea peninsula), and on the territory of two eastern regions (Lugansk and Donetsk) conducts military operations. This war is fought both on land and at sea. There is an actual blockade by the Russian Navy of the Ukrainian seaports on the Sea of Azov. On November 25, 2018, the Ukrainian Navy reported that the border ships of the Russian Navy "committed openly aggressive actions against the ships of the Ukrainian Navy". The Russian border ship has raided a Ukrainian raid tugboat; captured two armored boats and a tug of the Ukrainian Navy, captured military-men, three of the sailors were injured.

Experience gained suggests that full-scale wars are different from local military conflicts. Full-scale war arises due to deep-seated economic reasons and/or intractable political contradictions. Local military conflicts and hybrid warfare arise between the parties when the stronger side seeks to achieve superiority without entering into a full-scale war. The cause of such conflicts may be private factors related to territorial, ethnic, religious and other contradictions. Hybrid warfare does not require the involvement of significant forces and resources and does not affect a large part of society. However, such conflicts are characterized by a more complex interweaving of social and socio-psychological phenomena.

\footnotetext{
Methods:

A set of methods was used in the study: retrospective analysis of the emergence of military conflicts and the socio-political situation in Ukraine; abstraction and generalization of the influence of social psychological
}

phenomena on military-men's mental health; modeling of the medical-psychological support system for military-men of the National Guard of Ukraine.

\section{Results:}

Socio-psychological processes occurring in society have a strong influence on the mental health of the immediate participants in a local military conflict.

World statistics show that from $11 \%$ to $30 \%$ of military-men from different countries of the world are faced with post-traumatic syndrome. It should be noted that today there is no such reliable statistics for Ukraine. At the same time, it is known that not all military-men of the hybrid warfare in Ukraine are provided with medical-psychological support services. In military hospitals, most military-men are observed with mental disorders, behavior and nervous system diseases. Along with this, it can be stated that there is a shortage of specialized medical personnel - military psychologists and psychiatrists.

The urgency of the problem led to the choice of my research title.

The medical-psychological support model has been developed. The model includes medical component (medical diagnostics, medical therapy, medical correction, medical rehabilitation, medical prevention) and psychological component (psychodiagnostics, psychotherapy, psychocorrection, psychorehabilitation, psychoprevention).

\section{Conclusions:}

The model has enabled estimating mental health for military-men of National Guard of Ukraine who were participants of hybrid warfare, revealing tendencies and realizing prevention of mental disorders negative development, and also provided them with recovery and rehabilitation.

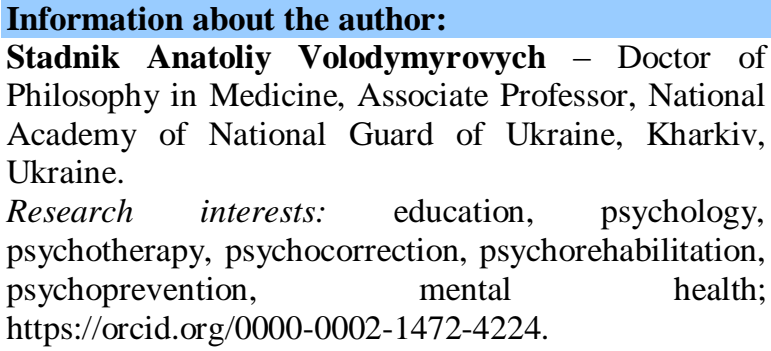

Corresponding Author:

Stadnik Anatoliy Volodymyrovych

Corresponding Author's Email: stav1963@ukr.net 